\title{
The Importance of Electromyographic Findings in Determining the Etiology of Mastalgia
}

\section{Mastaljinin Etiyolojisinin Saptanmasında Elektromiyografik Bulguların Önemi}

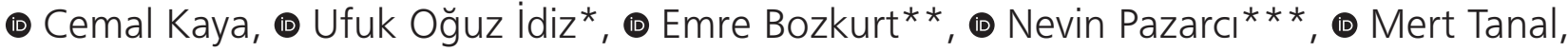 \\ ه Mehmet Mihmanlı
}

Şişli Hamidiye Etfal Training and Research Hospital, Clinic of General Surgery, Istanbul, Turkey

*istanbul Training and Research Hospital, Clinic of General Surgery, Istanbul, Turkey

**Kelkit State Hospital, Clinic of General Surgery, Gümüşhane, Turkey

***Şişli Hamidiye Etfal Training and Research Hospital, Clinic of Neurology, Istanbul, Turkey

Abstract

Aim: The etiology of mastalgia is not fully understood. We evaluated the relationship between electromyography (EMG) measurements of the pectoralis major (PM) muscle and mastalgia in patients with non-cyclic unilateral mastalgia.

Methods: Thirty-one patients who were admitted to the breast surgery outpatient clinic due to the complaints of intermittent or continuous unilateral non-cyclic mastalgia for at least one month were included in the study. Data on age, family history, age of menarche, body mass index (BMI), physical examination, breast ultrasonography and mammography findings and amplitudes, latency and cutaneous silent period (CSP) in EMG of the right and left PM muscles were noted.

Results: The mean age of the patients was 43.3 (20-65) years; mastalgia affected the left breast and the right breast in 22 $(71 \%)$ and nine $(29 \%)$, respectively. Twenty-three patients (74.1\%) had a BMI of $\geq 25 \mathrm{~kg} / \mathrm{m}^{2}$. There was a size difference between the two breasts in eleven patients. The EMG results of PM muscles in healthy and mastalgia sides were compared and there was no significant difference observed between the amplitude and resistance parameters. The mastalgia side had significantly higher CSP values.

Conclusion: Prolonged CSP suggests that unilateral mastalgia may be associated with pain modulating mechanisms of the central nervous system.

Keywords: Mastalgia, EMG, pectoralis major, cutaneous silent period

\section{Öz}

Amaç: Mastaljinin etiyolojisi tam olarak ortaya konulmamıştır. Periyodik olmayan tek taraflı mastalji hastalarında pektoralis majör kasının elektromiyografik ölçümleri ile mastalji arasındaki ilişkiyi değerlendirmeyi amaçladık.

Yöntemler: Meme cerrahisi polikliniğine tek taraflı periyodik olmayan mastalji şikayeti ile başvuran ve en az 1 aydır aralıklı veya devamlı mastalji şikayeti olan 31 hasta çalışmaya dahil edildi. Hastaların yaş, aile hikayesi, menarş yaşı, beden kitle indeksleri, fizik muayene bulguları, meme ultrasonografisi ve mamografi bulguları ile sağ-sol pektoralis majör kasının elektromiyografi amplitüt, latens ve kutanöz sessiz periyotları kayıt edildi.

Bulgular: Hastaların ortalama yaşı 43,3 (20-65) yıl; 22 (71\%) hastanın sol, dokuz (29\%) hastanın ise sağ mastalji şikayeti olduğu saptandı. Hastaların 23'ünün (74,1\%) beden kitle indeksi $\geq 25 \mathrm{~kg} / \mathrm{m}^{2}$ olarak saptandı. On bir hastanın sağ ve sol memesinde boyut farkı saptandı. Mastalji olan ve olmayan taraftaki pektoralis majör kasının elektromiyografi sonuçları karşılaştırıldı, amplitüt ve rezistans parametreleri açısından anlamlı fark saptanmadı. Mastalji olan taraf anlamlı oranda daha yüksek kutanöz sessiz periyot değerine sahipti.

Sonuç: Uzamış kutanöz sessiz periyot bulgusu tek taraflı mastaljinin santral sinir sisteminin ağrı düzenleme mekanizması ile ilişkili olabileceğini göstermektedir.

Anahtar Sözcükler: Mastalji, EMG, pektoralis majör, kutanöz sessiz periyot
Address for Correspondence/Yazışma Adresi: Cemal Kaya, Şişli Hamidiye Etfal Training and Research Hospital, Clinic of General Surgery, İstanbul, Turkey E-mail: drcemalkaya@gmail.com ORCID: orcid.org/0000-0002-6758-9089

Received/Geliş Tarihi: 29 August 2018 Accepted/Kabul Tarihi: 18 December 2018

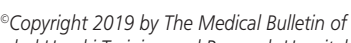
istanbul Haseki Training and Research Hospital The Medical Bulletin of Haseki published by Galenos Yayınevi.

${ }^{8}$ Telif Hakkı 2019 istanbul Haseki Eğitim ve Araştırma Hastanesi Haseki Tıp Bülteni, Galenos Yayınevi tarafından yayınlanmıştır. 


\section{Introduction}

Mastalgia refers to pain affecting one or both breasts (1). Nearly $80 \%$ of women experience breast pain at some point in their lives; yet the etiology of this pathology has not been fully elucidated (2). It has been reported that women with mastalgia complaints had moderate to severe pain and $11 \%$ of patients had mild pain. Mastalgia affects women's social, physical, sexual, and work life (35). One-third of mastalgia patients are classified as cyclic, as in the menstrual cycle, and one-third of are non-cyclic $(6,7)$. Cyclic mastalgia is especially severe in women during the reproductive period, and pain is usually bilateral. In a population-based survey, Ader et al. (6) found that $68 \%$ of women aged 18 to 44 experienced cyclic breast symptoms, and $22 \%$ of these rated their pain moderate to severe. Non-cyclic pain is not associated with menstrual cycle, often observed after menopause, usually unilateral and tends to be focal. This pain is often felt in the subareolar or medial half of the mammary gland (7).

The physiopathology of breast pain has not been fully elucidated. Elevated serum fatty acids, elevated basal prolactin levels, high-fat diet, smoking, and hormone replacement therapy are among the etiologic factors (814). Studies have shown that psychological factors also play a role in the etiology of mastalgia $(15,16)$. In addition, pain in the mammary gland itself, as well as pathologic diseases in the muscles, joints and bones around the breast may also cause mastalgia. Pain caused by pain syndromes or rheumatological diseases that effects the adjacent body parts (shoulder, arm or ribs) may also be felt as breast pain $(17,18)$.

In the literature, there have been studies suggesting a relationship between mastalgia and fibromyalgia that has been reported to affect 2.1\%-10.5\% of women (19-23). Electromyography (EMG) is one of the commonly used diagnostic methods for muscle and nervous system-related disorders such as fibromyalgia (24). The cutaneous silent period (CSP) is a useful tool for evaluating pain caused by the peripheral and central nervous system. CSP is an inhibitory spinal reflex which appears following strong electrical stimulation of a cutaneous nerve and causes suppression of voluntary muscle contraction for a certain period of time. The afferent arm of the CSP is formed by somatic small-diameter fibers. The CSP is a prospective electrophysiological method for the diagnosis of small fiber dysfunction. However, only a few studies have shown a relationship between CSP and fibromyalgia with chronic pain, and there are a limited number of studies evaluating the relationship between mastalgia and CSP (25-27).

In this study, we aimed to evaluate the relationship between pectoralis major (PM) muscle EMG measurements and mastalgia in patients with and without non-cyclic unilateral breast pain in order to elucidate the etiology of mastalgia.

\section{Methods}

This prospectively designed study started after the approval of the Şisli Hamidiye Etfal Education and Research Hospital Local Human Ethics Committee (no: NCT02784379). Mastalgia patients who were admitted to the breast surgery outpatient clinic at Şisli Hamidiye Etfal Education and Research Hospital between December 2015 and May 2016 comprised the study population. Inclusion criteria were 18-65 years of age, intermittent or continuous mastalgia complaints for at least 1 month, unilateral breast pain, and non-cyclic breast pain. Exclusion criteria included pregnancy, breastfeeding, breast surgery history, breast cancer history, cystic or solid lesion larger than $1 \mathrm{~cm}$ detected by mammography or ultrasonography (USG) suspected breast cancer, and orthopedic or neurological pathologies in the upper extremities, neck and thoracic region. Informed consent was obtained from all the patients included in the study, and a Clinical Trials application was completed at the beginning of the study (CT number: NCT02784379).

Data on patient age, family history, the number of children, age at menarche, body mass index (BMI), physical examination findings, and breast ultrasonography and mammography findings were recorded. Amplitude and latency measurements of the EMG (Viasys Healthcare, Synergy, Ireland) of the right and left PM muscle were noted. The EMG findings, motor distal latency and amplitudes of the PM muscle, CSP and spinal evoked potential (SEP) responses of the healthy and mastalgia sides of breasts were compared.

\section{Electrophysiological Method}

Concentric needle electromyography was performed on the deltoid, triceps, biceps, extender digitorum cominis, flexor carpi radialis, and 1st dorsal interosseus muscles, and measurements of the motor and sensory nerve conduction velocities and amplitudes of both upper extremities were performed on the basis of the pathologies that may lead to collar, shoulder and chest reflected sensory disturbances in all patients. As a result of these studies, patients with additional anomalies such as entrapment neuropathy and radiculopathy were not included in the study. After that, the following electrophysiological studies were carried out for mastalgia:

1) Needle electromyography of both PM muscles was performed

2) Recordings of superimposed electrical stimulation of the PM muscle by electrical stimulation of the PM muscle motor nerve from the Erb's point were analyzed. In addition, the process was repeated with a needle 
electrode. The distal latency of the motor nerve response obtained by both techniques and the amplitudes of the compound muscle action potential obtained by superficial recording electrodes were compared between the two sides of the breasts.

3) The PM muscle was used for the CSP evaluation. The supraclavicular nerve was stimulated superficially to the posterior border of the sternocleidomastoid muscle at a distance of $6 \mathrm{~cm}$ from the sternoclavicular joint and recordings were obtained from the PM muscle via bar electrode. Before the recording, the patient was asked to perform shoulder adduction with maximal effort and the maximal motor unit potential (MUP) amplitude was measured on the screen. The subjects were asked to perform shoulder adduction with MUP amplitudes of at least $25 \%$ of the maximal MUP amplitude. While the patient was constantly performing this adduction, the supraclavicular nerve was stimulated at $80 \mathrm{~mA}$ intensity, sweeps of $250 \mathrm{~ms}$ and duration of $0.5 \mathrm{~ms}$. Ten recordings were obtained at 30 second intervals. The CSP latency and duration were measured by assessing the average of 10 traces and compared between both sides of the breasts.

4) To evaluate wide-diameter fibers, superficial recording electrodes were placed on the PM muscle, and electrical stimulation of the axillary regions was performed. SEP response latencies of both sides of breasts were compared.

\section{Statistical analysis}

SPSS 21.0 (IBM Corp. Released 2012. IBM SPSS Statistics for Windows, Version 21.0. Armonk, NY: IBM Corp.) was used for statistical analysis. Descriptive statistics included mean, standard deviation, median, and quartile interval for numerical variables. Paired t-test was used to assess differences between numerical variables that conformed to a normal distribution condition, and the Wilcoxon sign test was used when normal distribution conditions were not met in the dependent group. The statistical significance level was set at $p<0.05$.

\section{Results}

Thirty-one patients with no USG and mammographic findings of mastalgia were enrolled in the study. The mean age of the patients was 43.3 (20-65) years; 22 patients (71\%) had complaints of mastalgia in the left breast and nine $(29 \%)$ in the right breast. Six (18.75\%) patients had a family history of breast cancer. Twenty-three patients $(74.1 \%)$ had a BMl of $\geq 25 \mathrm{~kg} / \mathrm{m}^{2}$. A size difference was observed between the breasts in 11 patients, and in eight of these patients, the mammary gland with mastalgia was larger (Table 1).

The EMG results of the PM muscle in the healthy and mastalgia sides of the breast tissue in the same patient were compared. No statistically significant difference was detected in amplitude and latency parameters of the EMG measurements between the groups ( $p>0.05$ ) (Table 2).

However, when the CSP of the right and left side PM muscle of the patients were evaluated, the CSP latency and duration on the mastalgia side was significantly longer compared with the non-mastalgia side $(p=0.024)$.

\section{Discussion}

Mastalgia may be a symptom of many breast-related diseases, but mastalgia can also occur for many reasons in patients without breast diseases. Mastalgia can also be induced by disorders of the skeletal and muscular systems, particularly via the pain associated with the location of the costochondral component and lateral involvement of the anterior axillary line (28). Mastalgia can also affect quality of life. In their study including 1171 participants, Ader et al. (4) reported that mastalgia interfered with usual sexual activity in $48 \%$ of women and with physical, social and work or school (6\%) activity in $37 \%, 12 \%$ and $6 \%$ of women, respectively.

The use of EMG to obtain information about muscle response or electrical activity to a nerve's stimulation of

\begin{tabular}{|l|l|}
\hline \multicolumn{2}{|l|}{ Table 1. Demographic and clinical characteristics of patients } \\
\hline Age (Mean \pm SD, year) & $43.3 \pm 17.6$ \\
\hline Age of menarche (Mean \pm SD, year) & $12.7 \pm 1.4$ \\
\hline Number of children & $3 \pm 1.2$ \\
\hline BMI (Mean \pm SD, $\mathrm{kg} / \mathrm{m}^{2}$ ) & $32.5 \pm 4.4$ \\
\hline $\begin{array}{l}\text { The number of patients who had size difference } \\
\text { between the two breasts (comparison of the size of the } \\
\text { right and left breasts by lateral and front view physical } \\
\text { examination in the same patient) }\end{array}$ & 11 \\
\hline SD: Standard deviation, BMl: Body mass index & \\
\hline
\end{tabular}

\begin{tabular}{|c|c|c|c|}
\hline & $\begin{array}{l}\text { Mastalgia } \\
(+)\end{array}$ & $\begin{array}{l}\text { Mastalgia } \\
(-)\end{array}$ & $p$ \\
\hline $\begin{array}{l}\text { CMAP amplitude recorded } \\
\text { in the PM muscle at the time } \\
\text { of electrical stimulus ( } \mathrm{mV}) \\
\text { Mean } \pm \text { SD }\end{array}$ & $2.40 \pm 1.52$ & $2.24 \pm 1.09$ & 0.552 \\
\hline $\begin{array}{l}\text { CMAP latency recorded in } \\
\text { the PM muscle at the time } \\
\text { of electrical stimulus (ms), } \\
\text { Mean } \pm \text { SD }\end{array}$ & $2.39 \pm 0.76$ & $2.36 \pm 0.53$ & 0.982 \\
\hline $\begin{array}{l}\text { CMAP latency recorded in } \\
\text { the PM muscle during an } \\
\text { unstimulated period (ms), } \\
\text { Mean } \pm \text { SD }\end{array}$ & $3.20 \pm 1.30$ & $3.19 \pm 1.91$ & 0.339 \\
\hline $\begin{array}{l}\text { Cutaneous silent period in the } \\
\text { PM muscle (ms), Mean } \pm \text { SD }\end{array}$ & $47.36 \pm 5.22$ & $45.72 \pm 4.50$ & 0.024 \\
\hline
\end{tabular}


a muscle provides information to the clinician regarding many conditions such as muscle aches, muscle weakness, anomalies related to muscle movements, and muscle atrophy $(24,29)$. Although many studies have evaluated the relationship between fibromyalgia and the nociceptive flexion reflex, we did not find any study evaluating the relationship of nociceptive flexion reflex with mastalgia $(30,31)$. Furthermore, only a few studies have evaluated the relationship between fibromyalgia and CSP, and we found no study investigating the relationship between mastalgia and CSP (25-27). Thus, our unique study was aimed at assessing EMG results in the PM muscle in the non-mastalgia and mastalgia sides of the breasts to determine whether unilateral mastalgia without organic breast disease is due to a muscle pathology.

Fibromyalgia and mastalgia share many similar features. For example, both are more prevalent in the female population, both are believed to develop due to stress, and both include clinical similarities $(30,32)$. In their study including 50 patients with mastalgia and 50 with fibromyalgia, Genc et al. (31) reported that $36 \%$ of mastalgia patients met fibromyalgia criteria, and $42 \%$ of fibromyalgia patients had mastalgia complaints. In another study by Sen et al. (30), $47.2 \%$ of 53 patients with fibromyalgia had mastalgia and $37.7 \%$ of 61 patients with mastalgia met the diagnostic criteria for fibromyalgia syndrome (30).

Studies on the relationship between exercise and mastalgia have reported that the incidence of mastalgia during physical activity varied between 29\% and 37\% $(3,4,33)$. In a study investigating mastalgia complaints seen in marathon runners, 32\% of 1285 runners reported mastalgia. In this study, mastalgia increased with increasing breast size, body mass index and exercise amount, and no relationship with age was detected. Approximately $17 \%$ of the participants in the study reported that they had to change their exercise programs due to mastalgia (33). However, in these studies, no information was provided regarding whether mastalgia was caused by muscular anomalies related to exercise. In our study, complaints of mastalgia were present on the side of the larger breast in 8 patients who had different breast sizes.

Few studies in the literature have explored the relationship between fibromyalgia and CSP. Umay et al. (25) compared CSP latency and duration in upper and lower extremities between 32 patients with fibromyalgia and 32 healthy controls and found that both upper and lower extremity CSP latencies in the EMG activity were higher in fibromyalgia patients. Baek et al. (27) compared CSP patterns between 24 patients with fibromyalgia patients and 24 healthy volunteers and reported that CSP duration values in fibromyalgia patients were significantly higher compared with controls and that longer CSP duration in fibromyalgia patients suggested central dysregulation at the spinal and supraspinal levels rather than peripheral small fiber dysfunction. In our study, CSP duration of the mastalgia side of the breasts was significantly longer. However, there was no significant difference for other EMG parameters.

The limitations of our study include the small number of patients and the fact that we did not examine the psychological status of the patients. In fact, some of the patients who met our study criteria did not accept psychiatric examination.

\section{Conclusion}

Albeit different reasons for mastalgia have been reported in the literature, a definite reason for mastalgia could not clearly be shown in these studies. CSP is thought to be prolonged due to dysfunction of the central nervous system mechanisms of pain modulation and because CSP has a role in pain. CSP in the EMG activity were monitored in our study with the aim of demonstrating that mastalgia may be due to central sensitization, which plays an important role in the formation of neuropathic pain, and our prolonged CSP results suggest a possible explanation for the etiology of this condition. In this respect, we believe that a larger contribution to understanding the etiology and developing treatments can be achieved with a wider series of cases.

\section{Authorship Contributions}

Concept: C.K., U.O.I., E.B., M.M., Design: C.K., U.O.I., E.B., M.M., Data Collection or Processing: C.K., E.B., N.P., M.T., Analysis or Interpretation: C.K., U.O.I., E.B., M.T., M.M., Literature Search: C.K., U.O.I., N.P., M.T., Writing: C.K., U.O.I., E.B., M.T., M.M.

Conflict of Interest: No conflict of interest was declared by the authors.

Financial Disclosure: The authors declared that this study received no financial support.

\section{References}

1. Mansel RE. The clinical assessment of mastalgia. Br J Clin Pract Suppl 1989; 68:17-20.

2. Carmichael AR. Can Vitex Agnus Castus be Used for the Treatment of Mastalgia? What is the Current Evidence? Evid Based Complement Alternat Med 2008;5:247-50.

3. Ader DN, Shriver CD. Cyclical mastalgia: prevalence and impact in an outpatient breast clinic sample. J Am Coll Surg 1997;185:466-70.

4. Ader DN, Browne MW. Prevalence and impact of cyclic mastalgia in a United States clinic-based sample. Am J Obstet Gynecol 1997;177:126-32. 
5. Colegrave S, Holcombe C, Salmon P. Psychological characteristics of women presenting with breast pain. J Psychosom Res 2001;50:303-7.

6. Ader DN, South-Paul J, Adera T, et al. Cyclical mastalgia: prevalence and associated health and behavioral factors. J Psychosom Obst Gyn 2001; 22:71-6.

7. Bishop HM, Blamey RW. A suggested classification of breast pain. Postgrad Med J 1979; 55:59-60.

8. Khan SA, Apkarian AV. Mastalgia and breast cancer: a protective association? Cancer Detection and Prevention 2002; 26: 192-6.

9. Heyden S, Muhlbaier LH. Prospective study of "fibrocystic breast disease" and caffeine consumption. Surgery 1984; 96:479-84.

10. Greendale GA, Reboussin BA, Hogan P, et al. Symptom relief and side effects of postmenopausal hormones: results from the Postmenopausal Estrogen/Progestin Interventions Trial. Obstet Gynecol 1998; 92:982-8.

11. Minton JP, Foecking MK, Webster DJ, et al. Caffeine, cyclic nucleotides, and breast disease. Surgery 1979; 86:105-9.

12. Bech P, Munk-Jensen N, Obel EB, et al. Combined versus sequential hormonal replacement therapy: a double-blind, placebo-controlled study on quality of life-related outcome measures. Psychother Psychosom 1998; 67:259-65.

13. Abraham GE. Nutritional factors in the etiology of the premenstrual tension syndromes. J Reprod Med 1983; 28:446-64.

14. Archer DR, Fischer LA, Rich D, et al. Estrace vs Premarin for treatment of menopausal symptoms: dosage comparison study. Advances in Therapy 1992;9:21-31.

15. Fox H, Walker LG, Heys SD,et al. Are patients with mastalgia anxious, and does relaxation therapy help? The Breast 1997; 6:138-42.

16. Kanat BH, Atmaca M, Girgin M, et al. Effects of Mastalgia in Young Women on Quality of Life, Depression, and Anxiety Levels. Indian J Surg. 2016;78:96-9.

17. Johnson KM, Bradley KA, Bush K, et al. Frequency of mastalgia among women veterans. Association with psychiatric conditions and unexplained pain syndromes. J Gen Intern Med 2006; 21(3):70-5.

18. Bilgin MG, Aydogan U, Bilgin S, et al. Meme agrisi sikayetiyle poliklinigimize muracaat eden hastalardaki meme kanseri sikliginin arastirilmasi. Turk Aile Hek Derg 2010; 14:8-12.

19. Wolfe F, Smythe HA, Yunus MB, et al. The American College of Rheumatology 1990 criteria for the classification of fibromyalgia: report of the multicenter criteria committee. Arthritis Rheum 1990;33:160-72.
20. Weir PT, Harlan GA, Nkoy FL, et al. The incidence of fibromyalgia and its associated comorbidities: a populationbased retrospective cohort study based on International Classification of Diseases, 9th Revision codes. J Clin Rheumatol 2006;12:124-8.

21. Wolfe F, Ross K, Anderson J, et al. The prevalence and characteristics of fibromyalgia in the general population. Arthritis Rheum 1995;38:19-28.

22. Lawrence RC, Helmick CG, Arnett FC, et al. Estimates of the prevalence of arthritis and selected musculoskeletal disorders in the United States. Arthritis Rheum 1998;41:778-99.

23. Forseth $\mathrm{KO}$, Gran JT. The prevalence of fibromyalgia among women aged 20-49 years in Arendal, Norway. Scand J Rheumatol 1992;21:74-8.

24. Silver J. Why do Electrodiagnostic Studies?. In: Weiss L, Silver J, Weiss J (eds). Easy EMG: A Guide to Performing Nerve Conduction Studies and Electromyography, Philadelphia. Elsevier; 2016. p. 5-8.

25. Umay $E$, Ulas $U$, Unlu $E$, et al. Importance of cutaneous silent period in fibromyalgia and its relationship with disease characteristics, psychological disorders and quality of life of patients. Rev Bras Reumatol 2013; 53:288-95.

26. Sahin O, Yildiz S, Yildiz N. Cutaneous silent period in fibromyalgia. Neurol Res. 2011; 33:339-43.

27. Baek SH, Seok HY, Koo YS, et al. Lengthened Cutaneous Silent Period in Fibromyalgia Suggesting Central Sensitization as a Pathogenesis. PLoS One. 2016;11:e0149248.

28. Maddox PR, Harrison BJ, Mansel RE, et al. Non-cyclical mastalgia: an improved classification and treatment. Britian Journal Sur 1989; 76; 901-4.

29. Silver J. What is an EMG. In: Weiss L, Silver J, Weiss J (eds). Easy EMG: A Guide to Performing Nerve Conduction Studies and Electromyography, Philadelphia. Elsevier; 2016. p. 1-4.

30. Sen M, Kilic MO, Cemeroglu O, et al. Can mastalgia be another somatic symptom in fibromyalgia syndrome? Clinics (Sao Paulo) 2015;70:733-7.

31. Genc V, Genc A, Ustuner E, et al. Is there an association between mastalgia and fibromyalgia? Comparing prevalence and symptom severity. Breast. 2011;20:314-8.

32. Akkus, S, Senol A, Ayvacioglu NB, et al. Is female predominance in irritable bowel syndrome related to fibromyalgia? Rheumatol Int. 2004;24:106-9.

33. Brown N, White J, Brasher A, et al. The experience of breast pain (mastalgia) in female runners of the 2012 London Marathon and its effect on exercise behaviour. $\mathrm{Br} J$ Sports Med 2014;48:320-5. 